\title{
The Mobile Phone Affinity Scale: Enhancement and Refinement
}

Beth C Bock ${ }^{1,2,3^{*}}$, PhD; Ryan Lantini ${ }^{1^{*}}$, MA; Herpreet Thind ${ }^{4 *}$, PhD; Kristen Walaska ${ }^{1 *}$, BS; Rochelle K Rosen ${ }^{1,3}$, $\mathrm{PhD}$; Joseph L Fava ${ }^{1 *}$, PhD; Nancy P Barnett ${ }^{5^{*}}, \mathrm{PhD}$; Lori AJ Scott-Sheldon ${ }^{1,2,3^{*}}, \mathrm{PhD}$

${ }^{1}$ Centers for Behavioral and Preventive Medicine, The Miriam Hospital, Providence, RI, United States

${ }^{2}$ Department of Psychiatry and Human Behavior, Alpert School of Medicine, Brown University, Providence, RI, United States

${ }^{3}$ Department of Behavioral and Social Sciences, School of Public Health, Brown University, Providence, RI, United States

${ }^{4}$ Department of Public Health, University of Massachusetts Lowell, Lowell, MA, United States

${ }^{5}$ Department of Behavioral and Social Sciences, Center for Alcohol and Addiction Studies, School of Public Health, Brown University, Providence, RI, United States

* these authors contributed equally

\section{Corresponding Author:}

Beth C Bock, PhD

Centers for Behavioral and Preventive Medicine

The Miriam Hospital

CORO Building, Suite 309

164 Summit Avenue

Providence, RI, 02906

United States

Phone: 14017938020

Fax: 14017938059

Email: Bbock@lifespan.org

\section{Abstract}

Background: Existing instruments that assess individuals' relationships with mobile phones tend to focus on negative constructs such as addiction or dependence, and appear to assume that high mobile phone use reflects pathology. Mobile phones can be beneficial for health behavior change, disease management, work productivity, and social connections, so there is a need for an instrument that provides a more balanced assessment of the various aspects of individuals' relationships with mobile phones.

Objective: The purpose of this research was to develop, revise, and validate the Mobile Phone Affinity Scale, a multi-scale instrument designed to assess key factors associated with mobile phone use.

Methods: Participants ( $\mathrm{N}=1058$, mean age 33) were recruited from Amazon Mechanical Turk between March and April of 2016 to complete a survey that assessed participants' mobile phone attitudes and use, anxious and depressive symptoms, and resilience.

Results: Confirmatory factor analysis supported a 6-factor model. The final measure consisted of 24 items, with 4 items on each of 6 factors: Connectedness, Productivity, Empowerment, Anxious Attachment, Addiction, and Continuous Use. The subscales demonstrated strong internal consistency (Cronbach alpha range $=0.76-0.88$, mean 0.83 ), and high item factor loadings (range=0.57-0.87, mean 0.75). Tests for validity further demonstrated support for the individual subscales.

Conclusions: Mobile phone affinity may have an important impact in the development and effectiveness of mobile health interventions, and continued research is needed to assess its predictive ability in health behavior change interventions delivered via mobile phones.

(JMIR Mhealth Uhealth 2016;4(4):e134) doi: 10.2196/mhealth.6705

\section{KEYWORDS}

mobile phone; psychometrics; assessment; measure 


\section{Introduction}

Mobile phones have shown promise as an effective delivery tool for health behavior change and disease management [1-6], and may be particularly well suited for interventions designed for young adults and adolescents. This population uses texting, apps, and other phone-based applications regularly, a trend that is particularly strong among younger age groups [7]. When developing an intervention that is delivered through mobile devices, it is important to consider how an individual uses his/her mobile phone, as mobile phone use may influence the receptivity to, and ultimately the efficacy of, mobile health (mHealth) programs and interventions $[8,9]$.

There are several published measures that assess the use of technology, including excessive mobile phone use and Internet addiction [10-13]. These measures are largely derived from the addictions and psychopathology literature, and are intended to measure problematic use of technology within a conceptual framework of use-as-pathology [13-15]. Problematic psychological constructs that have been linked to mobile phone use include impulsivity [11], depression [14], and anxiety [14]. However, mobile phones can serve many positive functions. For example, many apps now exist to help people track health behaviors (eg, exercise, weight loss) and manage medical conditions, including diabetes and asthma [16-18]. Mobile phones also serve positive functions, including increasing efficiency and productivity at work, and improving connectivity to social networks, family, and friends $[19,20]$. However, to our knowledge no measures assess mobile phone and technology use that include items reflective of these positive elements. Therefore, the goals of this study were to expand, revise, and validate the psychometric properties of the Mobile Phone Affinity Scale (MPAS) based on a version that we previously developed in a study of community college students [21]. The current study employs a national cross-sectional survey of adults living in the United States to identify important constructs related to mobile phone use, develop scales to measure these constructs, evaluate the internal consistency of the constructs, and establish the validity of the newly revised instrument.

\section{Methods}

\section{Questionnaire Development}

In the initial development of the MPAS, factors that may be associated with mobile phone use (and more broadly technology use) were identified by conducting a search of the relevant literature using PubMed. Identified constructs included social connectivity, dependence, addiction, mood, and continuous use [21]. To better assess positive functions of mobile phone use, the same search procedures were used in this study to expand the MPAS to include constructs related to empowerment, safety, and usefulness in the domains of social and personal use, and work and school-related use. Individuals from our research team independently wrote a series of items for each of these three additional constructs in English at a sixth grade reading level. The entire research team reviewed the items to determine face validity. Any confusing or ambiguous items were edited and duplicates were deleted. Instructions and response format were also reviewed for clarity. The resulting instrument contained 57 items measuring 7 constructs, with 6-to-9 items per construct, and used a Likert-type scale response format. This initial draft of the revised MPAS was then pretested with eight adults to confirm item clarity and comprehension before administering the measure to a larger sample.

\section{Psychometric Testing}

To test the MPAS, we conducted a national cross-sectional survey between March 25 and April 1, 2016, to assess respondents' mobile phone use, attitudes toward their mobile phone, current mood, demographic information, and other characteristics. Participants were registered users (workers) of Amazon Mechanical Turk (MTurk). We used MTurk to recruit for this survey since research has shown it to be a fast, inexpensive, reliable, and useful approach to collect data from a large and ethnically diverse sample [22-26].

To participate in the study, workers were redirected through the MTurk website to our project survey website, which presented detailed information about the study and an informed consent document. Interested workers who indicated their consent were then linked to the screening questions to assess eligibility. Workers were eligible to participate in the study if they were 18 years of age or older, lived in the United States, could read fluently in English, and owned a mobile phone. If eligible, participants were then directed to the full survey, which asked questions about their mobile phone use, attitudes toward their mobile phone, their current mood, and demographic information.

The online survey was managed using a secure Web-based application, Research Electronic Data Capture [27], hosted in our institution's Information Services department. Participants were compensated US \$1 upon completing the survey. No identifying information was asked of participants, thus keeping their responses anonymous. The informed consent process, assessment of eligibility, and completion of the surveys took an average of 17 minutes to complete. This study was approved by the Institutional Review Board at The Miriam Hospital.

\section{Measures}

\section{Mobile Phone Affinity Scale}

The initial MPAS consisted of 57 statements about mobile phone use. Participants were asked to report how true each statement was for them, using a 5-point Likert-type response format (1=not at all true to $5=$ extremely true).

\section{Other Measures}

In addition to the MPAS, participants responded to demographic questions regarding age, gender, race, ethnicity, education, employment status, and marital status. Participants also responded to questions about their mobile phone (ie, is it a smartphone?), the types of activities and apps used on the mobile phone, and the frequency with which they used text messaging.

Previous research has reported increased levels of anxiety, depression, and impulsivity associated with problematic mobile phone use [11,14], and since the MPAS was designed to assess both negative and positive constructs associated with mobile 
phone use, we included measures of these constructs to validate MPAS subscales. These measures were administered as part of the online questionnaire and included: (1) symptoms of anxiety, which were assessed using the 20-item State-Trait Anxiety Inventory (STAI) [28] which is scored on a 4-point scale (1=almost never to $4=$ =almost always), with higher scores indicating higher levels of anxiety; (2) depressive symptoms, which were measured using the 10-item Centers for Epidemiological Studies Depression Scale (CESD-10) [29] scored on a 4-point scale $(0=$ rarely/none of the time to $4=$ most/all of the time); and (3) impulsiveness, which was assessed using the 30-item Barratt Impulsiveness Scale (BIS-11) [30] scored on a 4-point scale (1=rarely/never to $4=$ almost always/always), with higher scores indicating greater impulsiveness. In addition, to differentiate subscales within the MPAS that we hoped would assess more positive and/or beneficial applications of mobile phone use, we chose psychological resilience as a positive psychological construct. We assessed this parameter using the 6-item Brief Resilience Scale (BRS) [31] scored on 5-point scale (1=strongly disagree to $5=$ strongly agree), with higher scores indicating greater psychological resilience.

\section{Statistical Analyses}

First, we used summary statistics (means, standard deviations, and frequencies) to describe the sample characteristics and measures for the entire sample. Second, a preliminary analysis was conducted to examine the MPAS item characteristics, and psychometric analyses were then conducted using confirmatory factor analysis (CFA) in Mplus Version 7.3 [32]. Model fit was evaluated based on the minimum fit function chi-square statistic, the comparative fit index (CFI; [33]), the nonnormed or
Tucker-Lewis index (TLI; [34]), the root means square error of approximation (RMSEA; [35]), the standardized root mean square residual (SRMR; [36]), and the model chi-square. Respecifications to the model were guided by theory, in combination with modification indices that are part of the statistical output, and designed to produce a brief measure of mobile phone attachment that is suitable for use in field research. Third, Cronbach alpha [37], a measure of internal consistency reliability, was estimated for each subscale. Finally, to test for concurrent validity of the final measure, we examined the association between MPAS subscales and measures of anxiety, depression, and impulsivity.

\section{Results}

\section{Participants}

Of the 1241 MTurk workers who were redirected to our survey website, $1.05 \%(13 / 1241)$ never completed the informed consent process, $5.32 \%(66 / 1241)$ of the potential participants completed the informed consent process but were deemed to be ineligible for the study, and $8.30 \%(103 / 1241)$ of the participants did not complete the survey. The data for one additional participant was corrupted and removed from the analyses.

Our analyses were restricted to the 1058 participants who agreed to participate in the study and completed all aspects of the survey. Participants were predominately white $(877 / 1058$; $82.89 \%)$. Men accounted for $49.91 \%$ (528/1058) of the participants, and women comprised 50.09\% (530/1058) of the sample. Participants were between 18 and 87 years of age (mean 32.5, standard deviation 10.3). Table 1 provides the complete demographic information for the sample. 
Table 1. Demographics for the overall sample $(\mathrm{N}=1058)$.

\begin{tabular}{|c|c|}
\hline Sample Characteristic & Proportion, \% (n) \\
\hline \multicolumn{2}{|l|}{ Sex } \\
\hline Male & $49.91(528)$ \\
\hline Female & $50.09(530)$ \\
\hline \multicolumn{2}{|l|}{ Race } \\
\hline White & $82.89(877)$ \\
\hline Black & $6.14(65)$ \\
\hline Asian & $5.01(53)$ \\
\hline Native Hawaiian & $0.47(5)$ \\
\hline Pacific Islander & $0.28(3)$ \\
\hline Other & $1.51(16)$ \\
\hline Multiple & $3.69(39)$ \\
\hline \multicolumn{2}{|l|}{ Ethnicity } \\
\hline Hispanic & $10.02(106)$ \\
\hline Non-Hispanic & $89.98(952)$ \\
\hline \multicolumn{2}{|l|}{ Marital status } \\
\hline Single & $51.13(541)$ \\
\hline Married & $39.89(422)$ \\
\hline Separated & $1.61(17)$ \\
\hline Divorced & $6.62(70)$ \\
\hline Widowed & $0.76(8)$ \\
\hline \multicolumn{2}{|l|}{ Census region } \\
\hline Northeast & $18.53(196)$ \\
\hline South & $39.13(414)$ \\
\hline Midwest & $21.17(224)$ \\
\hline West & $20.70(219)$ \\
\hline Pacific & $0.47(5)$ \\
\hline \multicolumn{2}{|l|}{ Education } \\
\hline High school or less & $10.87(115)$ \\
\hline Some college & $40.36(427)$ \\
\hline College degree or above & $48.68(515)$ \\
\hline \multicolumn{2}{|l|}{ Student } \\
\hline Yes, full-time & $14.37(152)$ \\
\hline Yes, part-time & $6.24(66)$ \\
\hline No & $79.30(839)$ \\
\hline \multicolumn{2}{|l|}{ Employed } \\
\hline Yes, full-time & $57.09(604)$ \\
\hline Yes, part-time & $20.42(216)$ \\
\hline No & $22.40(237)$ \\
\hline \multicolumn{2}{|l|}{ Income } \\
\hline$<\$ 25,000$ & $17.77(188)$ \\
\hline$\$ 25,000-\$ 49,999$ & $32.42(343)$ \\
\hline$\$ 50,000-\$ 99,999$ & $34.50(365)$ \\
\hline
\end{tabular}




\begin{tabular}{ll}
\hline Sample Characteristic & Proportion, \% (n) \\
\hline$>\$ 100,000$ & $11.53(122)$ \\
Missing & $3.78(40)$ \\
Living arrangement & \\
Alone & $18.34(194)$ \\
Spouse/partner & $30.91(327)$ \\
Adult roommate & $9.36(99)$ \\
Parents & $10.40(110)$ \\
Child(ren) & $3.78(40)$ \\
Spouse/partner and child(ren) & $22.59(239)$ \\
Multiple & $4.63(49)$ \\
\hline
\end{tabular}

\section{Dimensional and Internal Validity Analyses}

Preliminary item level analyses were conducted to examine individual item means, standard deviations, skew, and kurtosis in each of the 57 items, and the results were judged adequate to proceed with the dimensional analysis. An initial CFA model was fit using the full 57-item variable set and specified 7 correlated factors, with each of the items only allowed to load and be freely estimated on its hypothesized factor. This initial model fit poorly $\left(\chi_{1,518}^{2}=9375.0, \mathrm{RMSEA}=.07, \mathrm{CFA}=.79\right.$, TLI=.78, SRMR=.071). The model fit was improved by removing items with poor loadings $(<.4)$, very high cross-factor error correlations, or potentially high cross-factor loading, which indicated a complex item. One further adjustment included collapsing the initially posited separate factors of safety and empowerment into a single factor, based on the modification indices and conceptual similarity of the item content.

The final model $\left(\chi_{237}^{2}=1100.9, \mathrm{RMSEA}=.059, \mathrm{CFA}=.941\right.$, TLI=.931, SRMR=.042) represented a parsimonious and balanced solution with 6 correlated factors, each measured by 4 items, creating a final measure consisting of 24 items
(Multimedia Appendix 1). This 24-variable solution fit very well based on alternative criteria suggested by $\mathrm{Hu}$ and Bentler [38] and did not use any superfluous adjustments, such as freeing error covariance parameters or allowing variables to load on additional factors, to achieve the final improved model fit. Individual item loadings were high for all items on their respective factors (range $=0.57-0.87$, mean 0.75; see Table 2), and internal consistency reliability was also very good for each factor, as measured by Cronbach alpha (range $=0.76-0.88$, mean 0.83 ; see Table 2). The disattenuated correlations for the latent constructs are presented in Table 3.

Concurrent validity analyses examined correlations between each MPAS subscale and measures of depressive symptoms (CESD-10), anxiety (STAI), resilience (BRS), and impulsiveness (BIS). Depressive symptoms, anxiety, and impulsivity were significantly correlated with Anxious Attachment, Addiction, and Continuous Use subscales, but not with the Connectedness, Productivity, or Empowerment subscales. Resilience was significantly negatively correlated with scores on the Addiction and Anxious Attachment subscales and positively correlated with the Productivity subscale (Table 4). 
Table 2. Confirmatory factor analyses, item loadings, and Cronbach coefficient alpha for 6 correlated factors that were modeled using the whole sample.

\begin{tabular}{lllll}
\hline Parameter & Connectedness & Productivity Empowerment Anxious & Addiction & Continuous \\
Use & & Attachment & \\
\hline
\end{tabular}

My phone helps me keep track of my social life $\quad .76$

When it comes to my health or social life, my $\quad .71$

phone is my personal assistant

My phone helps me stay close to my friends and $\quad .70$

family

My phone makes it easy to cancel plans with

.60

others

My phone helps me to be more organized at

work/school

I use my phone to connect with my co-workers

or other students

My phone is necessary for work/school

My phone helps me stay up-to-date with

work/school activities

Having my phone with me makes it easier to

leave a risky situation

I feel in control when I have my phone with me

My phone gives me a sense of security

I feel safe when I have my phone with me

I feel anxious if I don't have my phone with me

I feel isolated without my phone

I feel dependent on my phone

Without my mobile phone, I feel out of touch with the world

I find myself occupied on my phone even when

I'm with other people

I find myself occupied with my phone when I

should be doing other things

I find myself engaged with my mobile phone for

longer periods of time than I intended

I would get more work done if I spent less time on my phone

I read/send text messages from my mobile phone, when I am at work or in class, that are not related to what I am doing

I use my phone all day

I am never bored if I have my phone with me

I rely on my phone $24 / 7$ 
Table 3. Disattenuated correlations among 6 latent constructs from confirmatory factor analyses (upper-right triangle), with the raw summated scale score correlations (lower-left triangle).

\begin{tabular}{|c|c|c|c|c|c|c|}
\hline & Connectedness & Productivity & Empowerment & $\begin{array}{l}\text { Anxious } \\
\text { Attachment }\end{array}$ & Addiction & Continuous Use \\
\hline Connectedness & - & .74 & .82 & .77 & .66 & .81 \\
\hline Productivity & .60 & - & .55 & .53 & .46 & .65 \\
\hline Empowerment & .69 & .48 & - & .78 & .47 & .69 \\
\hline Anxious Attachment & .63 & .45 & .68 & - & .72 & .84 \\
\hline Addiction & .54 & .40 & .41 & .61 & - & .78 \\
\hline Continuous Use & .65 & .55 & .57 & .68 & .67 & - \\
\hline
\end{tabular}

Table 4. Correlations for complete sample among the 6 Mobile Phone Affinity Scale (MPAS) scores and Centers for Epidemiologic Studies Depression Scale (CESD), State-Trait Anxiety Inventory (STAI), Barratt Impulsiveness Scale (BIS-11), and Brief Resilience Scale (BRS).

\begin{tabular}{|c|c|c|c|c|c|c|c|c|}
\hline & $\begin{array}{l}\text { Dep } \\
(\mathrm{CE}\end{array}$ & & $\begin{array}{l}\text { Anxiety } \\
\text { (STAI) }\end{array}$ & & $\begin{array}{l}\text { Impulsivity } \\
\text { (BIS-11) }\end{array}$ & & $\begin{array}{l}\text { Resilience } \\
\text { (BRS) }\end{array}$ & \\
\hline & $\mathrm{r}^{\mathrm{a}}$ & $P$ value & $\mathrm{r}^{\mathrm{a}}$ & $P$ value & $\mathrm{r}^{\mathrm{a}}$ & $P$ value & $\mathrm{r}^{\mathrm{a}}$ & $P$ value \\
\hline Connectedness & .03 & .36 & -.00006 & .99 & .01 & .81 & .06 & .07 \\
\hline Productivity & .02 & .56 & -.04 & .20 & -.04 & .21 & .09 & $<.001$ \\
\hline Empowerment & .02 & .51 & .03 & .39 & -.01 & .64 & .00 & .95 \\
\hline Anxious & .13 & $<.001$ & .15 & $<.001$ & .13 & $<.001$ & -.12 & $<.001$ \\
\hline \multicolumn{9}{|l|}{ Attachment } \\
\hline Addiction & .25 & $<.001$ & .18 & $<.001$ & .29 & $<.001$ & -.15 & $<.001$ \\
\hline Continuous Use & .10 & $<.001$ & .08 & .01 & .14 & $<.001$ & -.03 & .28 \\
\hline
\end{tabular}

${ }_{\mathrm{r}=\text { Pearson product-moment correlation coefficient }}^{\mathrm{a}}$

\section{Discussion}

This study developed, revised, and validated the MPAS, a multi-dimensional survey instrument with strong internal consistency and high item factor loadings across 6 distinct subscales. The MPAS provides a measure of an individual's relationship to his/her mobile phone with positive (Connectedness, Productivity, Empowerment), negative (Anxious Attachment, Addiction), and neutral (Continuous Use) valences. Results showed that the subscales we conceived of as positive (eg, Connectedness) were not correlated with depressive symptoms, anxiety, or impulsivity, while both negative subscales (Anxious Attachment, Addiction) were correlated with these features. Personal resilience, a positive characteristic, was significantly and positively correlated with affinity for the mobile phone for Productivity purposes and negatively correlated with both negative subscales. This finding differentiates the MPAS from other instruments in that both impulsivity and anxiety have been shown to be associated with mobile phone use in studies of mobile phone addiction or dependence [39-41]. However, the Connectedness subscale was not correlated with resilience, which is reasonable given that personal relationships with others can help promote personal resilience $[42,43]$, but can also place a burden on individuals [44]. Thus, no clear positive or negative association with resilience would be expected among those with high affinity for using their mobile phone for social connections.
In this revision of the MPAS, we have succeeded in our goal of creating a scale that represents both positive and negative aspects of increased use of mobile technology. Using the previous 4-subscale version, most scales were correlated with anxiety-related and depressive symptoms [21], while a much clearer differentiation was observed in the present 6-subscale version. In the current revised version, only Continuous Use, Anxious Attachment, and Addiction were associated with depressive symptoms, while use of mobile phones for Connectedness, Productivity, and Empowerment were not. Furthermore, in the current version of the MPAS, the Continuous Use subscale is correlated with anxiety, but less strongly than the Anxious Attachment or Addiction subscales, suggesting that some level of anxiety can be a positive, functional trait, by enhancing attentiveness to important things (eg, making sure to bring your phone with you or ensuring the battery is charged).

\section{Limitations}

Ultimately, we anticipate the value of the MPAS will be to provide predictive value for $\mathrm{mHealth}$ interventions, necessitating the assessment of whether scores on the MPAS (or any of its subscales) relate significantly to outcomes of interventions. However, this instrument was not developed in the context of an intervention study, and it is a limitation of this study that we did not assess other factors (eg, intentions to change health behaviors or outcome expectations) that may have served as a proxy for intervention outcomes. A second important limitation relates to the nature of the study sample. Although MTurk 
workers tend to be racially and ethnically diverse, they are likely to be more technologically savvy than most mobile phone users, and may not be representative of the overall US population in that regard. Thus, it is possible that the mean value of any individual MPAS subscale may differ between the MTurk study sample and other US population samples, but the high internal consistency reliability of each subscale, and the associated high item loadings on each subscale, indicate that the instrument has strong internal validity. We expect that this instrument will prove valuable for its intended purposes when used in other adult samples.

\section{Future Directions}

Additional work is needed to examine whether scores on the MPAS or its subscales are predictive of uptake, maintenance, and successful outcomes among individuals who are interacting with a behavioral health intervention delivered (in whole or in part) through mobile technology. It is our hope that the MPAS developed in this study may prove to be a useful indicator of the quality of the individual's relationship with their mobile phone, and may comprise an important element in understanding the efficacy of mHealth interventions and programs.
There is tremendous growth in technologies that can provide health care and behavioral health interventions through mobile channels, such as apps and text messaging [16-18]. While the qualities of both the intervention and the delivery technology are important, in our quest to understand the effects that these interventions have on behaviors, it is also important to understand the relationship that the individual has with their mobile phone. mHealth involves not only health behaviors, but also those behaviors and attitudes relevant to interacting with mobile technology, and interacting with other people through mobile devices. Given the immediate and reciprocal nature of both health behavior and the behavior of interacting with a mobile device, thought leaders have suggested that our current behavioral health theories may be inadequate, particularly as mHealth interventions become increasingly interactive and adaptive [45]. Several papers have called for an expansion of our understanding of how interacting with a mobile device impacts health behavior [46,47]. Research is needed that can contribute to new theories regarding the interaction between mobile technology use, mHealth interventions, and behavior change.

\section{Acknowledgments}

Research reported in this paper was supported by the National Institute on Drug Abuse of the National Institutes of Health (award number R01DA027142), which was awarded to Dr Bock. The content of this paper is solely the responsibility of the authors and does not necessarily represent the official views of the National Institutes of Health.

\section{Conflicts of Interest}

None declared.

\section{Multimedia Appendix 1}

Final 24-item Mobile Phone Affinity Scale.

[PDF File (Adobe PDF File), 46KB-Multimedia Appendix 1]

\section{References}

1. Siopis G, Chey T, Allman-Farinelli M. A systematic review and meta-analysis of interventions for weight management using text messaging. J Hum Nutr Diet 2015 Feb;28 Suppl 2:1-15. [doi: 10.1111/jhn.12207] [Medline: 24480032]

2. Head KJ, Noar SM, Iannarino NT, Grant HN. Efficacy of text messaging-based interventions for health promotion: a meta-analysis. Soc Sci Med 2013 Nov;97:41-48. [doi: 10.1016/j.socscimed.2013.08.003] [Medline: 24161087]

3. Finitsis DJ, Pellowski JA, Johnson BT. Text message intervention designs to promote adherence to antiretroviral therapy (ART): a meta-analysis of randomized controlled trials. PLoS One 2014;9(2):e88166 [FREE Full text] [doi: 10.1371/journal.pone.0088166] [Medline: 24505411]

4. Whittaker R, McRobbie H, Bullen C, Borland R, Rodgers A, Gu Y. Mobile phone-based interventions for smoking cessation. Cochrane Database Syst Rev 2012;11:CD006611. [doi: 10.1002/14651858.CD006611.pub3] [Medline: 23152238]

5. Scott-Sheldon LA, Lantini R, Jennings EG, Thind H, Rosen RK, Salmoirago-Blotcher E, et al. Text messaging-based interventions for smoking cessation: a systematic review and meta-analysis. JMIR Mhealth Uhealth 2016;4(2):e49 [FREE Full text] [doi: 10.2196/mhealth.5436] [Medline: 27207211]

6. Free C, Phillips G, Watson L, Galli L, Felix L, Edwards P, et al. The effectiveness of mobile-health technologies to improve health care service delivery processes: a systematic review and meta-analysis. PLoS Med 2013 Jan;10(1):e1001363 [FREE Full text] [doi: 10.1371/journal.pmed.1001363] [Medline: 23458994]

7. Bock BC, Rosen RK, Barnett NP, Thind H, Walaska K, Foster R, et al. Translating behavioral interventions onto mHealth platforms: developing text message interventions for smoking and alcohol. JMIR Mhealth Uhealth 2015;3(1):e22 [FREE Full text] [doi: 10.2196/mhealth.3779] [Medline: 25714907]

8. Duggan M. Cell phone activities. Pew Research Center Internet \& American Life Project. Washington, DC; 2013. URL: http://www.pewinternet.org/2013/09/19/cell-phone-activities-2013/ [accessed 2016-08-23] [WebCite Cache ID 6jytbp1AY] 
9. Duggan M. Pew Research Center Internet \& American Life Project. Mobile messaging and social media. Pew Research Center Internet \& American Life Project. Washington, DC; 2015. URL: http://www.pewinternet.org/2015/08/19/ mobile-messaging-and-social-media-2015/ [accessed 2016-08-23] [WebCite Cache ID 6jytp07LY]

10. Bianchi A, Phillips JG. Psychological predictors of problem mobile phone use. Cyberpsychol Behav 2005 Feb;8(1):39-51. [doi: $10.1089 / \mathrm{cpb} .2005 .8 .39]$ [Medline: 15738692 ]

11. Billieux J. Problematic use of the mobile phone: a literature review and a pathways model. CPSR 2012 Oct 01;8(4):299-307. [doi: 10.2174/157340012803520522]

12. Merlo LJ, Stone AM, Bibbey A. Measuring problematic mobile phone use: development and preliminary psychometric properties of the PUMP scale. J Addict 2013;2013:912807 [FREE Full text] [doi: 10.1155/2013/912807] [Medline: 24826371]

13. Jenaro C, Flores N, Gómez-Vela M, González-Gil F, Caballo C. Problematic internet and cell-phone use: psychological, behavioral, and health correlates. Addict Res Theory 2009 Jul 11;15(3):309-320. [doi: 10.1080/16066350701350247]

14. Thomée S, Härenstam A, Hagberg M. Mobile phone use and stress, sleep disturbances, and symptoms of depression among young adults--a prospective cohort study. BMC Public Health 2011;11:66 [FREE Full text] [doi: 10.1186/1471-2458-11-66] [Medline: 21281471]

15. Augner C, Hacker GW. Associations between problematic mobile phone use and psychological parameters in young adults. Int J Public Health 2012 Apr;57(2):437-441. [doi: 10.1007/s00038-011-0234-z] [Medline: 21290162]

16. Klasnja P, Pratt W. Healthcare in the pocket: mapping the space of mobile-phone health interventions. J Biomed Inform 2012 Feb;45(1):184-198 [FREE Full text] [doi: 10.1016/j.jbi.2011.08.017] [Medline: 21925288]

17. Krishna S, Boren SA, Balas EA. Healthcare via cell phones: a systematic review. Telemed J E Health 2009 Apr;15(3):231-240. [doi: 10.1089/tmj.2008.0099] [Medline: 19382860]

18. Peterson A. Improving type 1 diabetes management with mobile tools: a systematic review. J Diabetes Sci Technol 2014 Jul;8(4):859-864 [FREE Full text] [doi: 10.1177/1932296814529885] [Medline: 24876414]

19. Walsh SP, White KM, Cox S, Young RM. Keeping in constant touch: the predictors of young Australians' mobile phone involvement. Comput Human Behav 2011 Jan;27(1):333-342. [doi: 10.1016/j.chb.2010.08.011]

20. Walsh S, White KM, McD Young R. Needing to connect: the effect of self and others on young people's involvement with their mobile phones. Aus J Psych 2010 Dec;62(4):194-203. [doi: 10.1080/00049530903567229]

21. Bock B, Thind H, Fava J, Walaska K, Barnett N, Rosen R, et al. Development of the mobile phone attachment scale. 2016 Jan 05 Presented at: 49th Hawaii International Conference on System Sciences (HICSS); January 2016; Kauai, Hawaii p. 5-8. [doi: 10.1109/HICSS.2016.424]

22. Paolacci G, Chandler J. Inside the Turk: understanding Mechanical Turk as a participant pool. Curr Dir Psychol Sci 2014 Jun 03;23(3):184-188. [doi: 10.1177/0963721414531598]

23. Paolacci G, Chandler J, Ipeirotis P. Running experiments on Amazon Mechanical Turk. Judgm Decis Mak 2010;5(5):411-419.

24. Buhrmester M, Kwang T, Gosling SD. Amazon's Mechanical Turk: a new source of inexpensive, yet high-quality, data? Perspect Psychol Sci 2011 Jan;6(1):3-5. [doi: 10.1177/1745691610393980] [Medline: 26162106]

25. Berinsky AJ, Huber GA, Lenz GS. Evaluating online labor markets for experimental research: Amazon.com's Mechanical Turk. Political Analysis 2012 Mar 02;20(3):351-368. [doi: 10.1093/pan/mpr057]

26. Mason W, Suri S. Conducting behavioral research on Amazon's Mechanical Turk. Behav Res Methods 2012 Mar;44(1):1-23. [doi: 10.3758/s13428-011-0124-6] [Medline: 21717266]

27. Harris PA, Taylor R, Thielke R, Payne J, Gonzalez N, Conde JG. Research electronic data capture (REDCap)--a metadata-driven methodology and workflow process for providing translational research informatics support. J Biomed Inform 2009 Apr;42(2):377-381 [FREE Full text] [doi: 10.1016/j.jbi.2008.08.010] [Medline: 18929686]

28. Spielberger CD, Gorsuch RL, Lushene R, Vagg PR, Jacobs GA. Manual for the state-trait anxiety inventory. Palo Alto, CA: Consulting Psychologists Press; 1983.

29. Andresen EM, Malmgren JA, Carter WB, Patrick DL. Screening for depression in well older adults: evaluation of a short form of the CES-D (Center for Epidemiologic Studies Depression Scale). Am J Prev Med 1994 Mar;10(2):77-84. [Medline: $\underline{8037935]}$

30. Patton JH, Stanford MS, Barratt ES. Factor structure of the Barratt impulsiveness scale. J Clin Psychol 1995 Nov;51(6):768-774. [Medline: $\underline{8778124]}$

31. Smith BW, Dalen J, Wiggins K, Tooley E, Christopher P, Bernard J. The brief resilience scale: assessing the ability to bounce back. Int J Behav Med 2008;15(3):194-200. [doi: 10.1080/10705500802222972] [Medline: 18696313]

32. Muthén L, Muthén B. Mplus User's Guide. Seventh Edition. Los Angeles, CA: Muthén \& Muthén; 1998.

33. Bentler PM. Comparative fit indexes in structural models. Psychol Bull 1990 Mar;107(2):238-246. [Medline: 2320703]

34. Tucker LR, Lewis C. A reliability coefficient for maximum likelihood factor analysis. Psychometrika 1973 Mar;38(1):1-10. [doi: $10.1007 / \mathrm{BF} 02291170$ ]

35. Steiger JH. Structural model evaluation and modification: an interval estimation approach. Multivariate Behav Res 1990 Apr 01;25(2):173-180. [doi: 10.1207/s15327906mbr2502 4] [Medline: 26794479]

36. Bentler P. EQS: a structural equations program manual. Los Angeles, CA: BMDP Statistical Software; 1989.

37. Cronbach LJ. Coefficient alpha and the internal structure of tests. Psychometrika 1951 Sep;16(3):297-334. [doi: 10.1007/BF02310555] 
38. Hu L, Bentler PM. Cutoff criteria for fit indexes in covariance structure analysis: conventional criteria versus new alternatives. Struct Equ Modeling 1999 Jan;6(1):1-55. [doi: 10.1080/10705519909540118]

39. Billieux J, Van der Linden M, Rochat L. The role of impulsivity in actual and problematic use of the mobile phone. Appl Cognit Psychol 2008 Dec;22(9):1195-1210. [doi: 10.1002/acp.1429]

40. Choliz M. Mobile-phone addiction in adolescence: the test of mobile phone dependence (TMD). Prog Health Sci 2012;2(1):33-44.

41. King AL, Valença AM, Silva AC, Sancassiani F, Machado S, Nardi AE. "Nomophobia": impact of cell phone use interfering with symptoms and emotions of individuals with panic disorder compared with a control group. Clin Pract Epidemiol Ment Health 2014;10:28-35 [FREE Full text] [doi: 10.2174/1745017901410010028] [Medline: 24669231]

42. Kawachi I, Berkman LF. Social ties and mental health. J Urban Health 2001 Sep;78(3):458-467 [FREE Full text] [doi: 10.1093/jurban/78.3.458] [Medline: $\underline{11564849}$ ]

43. van Kessel G. The ability of older people to overcome adversity: a review of the resilience concept. Geriatr Nurs 2013;34(2):122-127. [doi: 10.1016/j.gerinurse.2012.12.011] [Medline: 23332474]

44. Pemberton R, Fuller Tyszkiewicz MD. Factors contributing to depressive mood states in everyday life: a systematic review. J Affect Disord 2016 Aug;200:103-110. [doi: 10.1016/j.jad.2016.04.023] [Medline: 27131503]

45. Fiordelli M, Diviani N, Schulz PJ. Mapping mHealth research: a decade of evolution. J Med Internet Res 2013;15(5):e95 [FREE Full text] [doi: 10.2196/jmir.2430] [Medline: 23697600]

46. de la Vega R, Miró J. mHealth: a strategic field without a solid scientific soul. A systematic review of pain-related apps. PLoS One 2014;9(7):e101312 [FREE Full text] [doi: 10.1371/journal.pone.0101312] [Medline: 24999983]

47. Riley WT, Rivera DE, Atienza AA, Nilsen W, Allison SM, Mermelstein R. Health behavior models in the age of mobile interventions: are our theories up to the task? Transl Behav Med 2011 Mar;1(1):53-71 [FREE Full text] [doi: 10.1007/s13142-011-0021-7] [Medline: 21796270]

\author{
Abbreviations \\ BIS-11: Barratt Impulsiveness Scale \\ BRS: Brief Resilience Scale \\ CESD-10: Centers for Epidemiologic Studies Depression Scale \\ CFA: confirmatory factor analysis \\ CFI: Comparative Fit Index \\ mHealth: mobile health \\ MPAS: Mobile Phone Affinity Scale \\ MTurk: Amazon Mechanical Turk Service \\ RMSEA: root mean square error of approximation \\ SRMR: standardized root mean square residual \\ STAI: State-Trait Anxiety Inventory \\ TLI: Tucker-Lewis Index
}

\author{
received 07.11.16; accepted 23.11.16; published 15.12 .16 \\ Please cite as: \\ Bock BC, Lantini R, Thind H, Walaska K, Rosen RK, Fava JL, Barnett NP, Scott-Sheldon LAJ \\ The Mobile Phone Affinity Scale: Enhancement and Refinement \\ JMIR Mhealth Uhealth 2016;4(4):e134 \\ URL: http://mhealth.jmir.org/2016/4/e134/ \\ doi: $10.2196 /$ mhealth.6705
}

Edited by G Eysenbach; submitted 26.09.16; peer-reviewed by N Diviani, P Schulz; comments to author 02.11.16; revised version

PMID: 27979792

(CBeth C Bock, Ryan Lantini, Herpreet Thind, Kristen Walaska, Rochelle K Rosen, Joseph L Fava, Nancy P Barnett, Lori AJ Scott-Sheldon. Originally published in JMIR Mhealth and Uhealth (http://mhealth.jmir.org), 15.12.2016. This is an open-access article distributed under the terms of the Creative Commons Attribution License (http://creativecommons.org/licenses/by/2.0/), which permits unrestricted use, distribution, and reproduction in any medium, provided the original work, first published in JMIR mhealth and uhealth, is properly cited. The complete bibliographic information, a link to the original publication on http://mhealth.jmir.org/, as well as this copyright and license information must be included. 